\title{
ON THE SUPPOSED ORIGIN OF THE MOLDAVITES AND LIKE SPORADIC GLASSES FROM VARIOUS SOURCES.
}

\author{
By George P. Merrill, \\ Head Curator of Geology, U. S. National Museum.
}

Peculiar pebbles of a greenish, chrysolite-like glass found in the gravels in regions remote from volcanoes or manufactories attracted the attention of observers in Bohemia and Moravia as long ago as 1787. The literature since that date contains numerous references to these and somewhat similar occurrences in India, Australia, and other widely separated localities, the descriptive matter as a rule being accompanied by speculations regarding the ultimate source of the materials. It is the purpose of the present paper to discuss these various finds with particular reference to their origin, and incidentally to describe several allied forms concerning the nature of which there is apparently no question. ${ }^{1}$ Inasmuch, however, as no object of this nature has yet been described in America, and as, consequently, its literature is almost entirely silent on the subject, a brief review is perhaps admissible here.

In Moravia and Bohemia the objects are found with quartz pebbles in the late Diluvian and Tertiary conglomerates, but are never referable directly to the same. In Java they are found in Quaternary tuffs and in the platinum mines southeast of Borneo. On the island of Billiton they are found in the Quaternary and perhaps Pliocene tin-bearing gravels. In Australia they have been found mainly on the surface of the ground, and no positive proof of their existence in Tertiary beds has as yet appeared. According to information received from Mr. George W. Card, of the Mining and Geological Museum, Sydney, the examples from Bimbowrie in southern Australia were found on a plain thickly covered with weathered quartz which resulted from the denudation of the adjacent quartz reefs. Most of them were broken and shattered as though by a fall; all lay loosely on the surface.

\footnotetext{
1 For a full bibliography of the subject up to and including 1898, see Franz E. Suess, Die Herkunft der Moldavite und verwandter Gläser, Jahrb. d. k. k. geol. Reichsanstalt, Heft. 2, vol. 50, 1900, pp. 193-381. This includes 55 titles referring to the occurrences in Europe, the Sunda Archipelago, and Australia. A bibliography of the Australian and Tasmanian occurrences is given by R. H. Walcott in his paper on The Occurrence of So-called Obsidian Bombs, in the Proc. Roy. Soc. Victoria, 1898, pp. 23-52.
}

Proceedings U. S. National Museum, Vol. 40-No. 1833. 80796 -Proc.N.M.vol.40-11-31 
In appearance and general physical properties these various bodies from the widely separated sources possess certain points in common, but are yet so different in appearance that examples from any one locality are readily recognized. The Moravian and Bohemian forms, as will be noted by reference to pl.61, figs. 4-6, are more or less rounded pebbles or flattened slag-like masses, the surfaces of which are pitted in a way which has been compared by some writers to the thumb-like pittings on meteorites. In addition to this, they are dulled and rendered opaque through abrasion from other stony particles very much like ordinary pebbles from the bed of a stream. In some instances they are deeply cut or notched as in fig. 5. The colors are chrysolite green, and the refractive index so high that they have in some instances been cut and utilized as gems.

The examples from Billiton, shown in pl. 61, figs. 1-3, are much more remarkable both on account of their shape and the extraordinary groovings which traverse the surface in all directions. They are of a deep, lustrous black color and translucent only on the thinnest edges.

The Australian and Tasmanian occurrences have more the appearance of water-worn pebbles which have been abraded by wind-blown sand (pl. 61, figs. 7-9). These are also black and opaque excepting on the thinnest edges. In all, the glass is wholly amorphous without trace of the trichites so characteristic of obsidian and other volcanic glasses. A few characteristic forms only are shown on pl. 61 of this paper; for a complete series the reader is referred to the work of Franz Suess already noted.

Chemically, as will be noted in the selected analyses referred to later, these forms are all acid glasses approximating in composition the glassy forms of terrestrial rhyolites but unusually rich in lime and magnesia. They are also remarkable for their small water content as indicated by loss on ignition, and their high fusing point.

In none of the occurrences are the objects found in regions of volcanic rocks and under conditions which seem to render it at all likely that they are of local derivation. It is seemingly impossible to conceive of their having been ejected as volcanic bombs and drifted by winds, and equally impossible, apparently, that they should belong to either stream or glacial drift. An artificial origin is likewise considered impossible by the majority of those who have given the subject consideration, and of late those who should be best qualified to judge have been disposed to consider them as of a meteoric nature. It is with especial reference to this view that the accompanying paper has been prepared.

Aside from the conditions under which these objects (which have come to be known under the names of "Moldavites," "Billitonites," "Australites," "Obsidianites," and "Obsidian bombs," and which 
Suess has suggested should all be included under the name of "tektites"), are found, their most striking characteristic is the peculiar markings, which, in the case of those of the island of Billiton, it would seem well-nigh impossible to explain in the present condition of our knowledge. Suess, to whose monograph I am indebted for the most detailed and comprehensive of recorded observations, regards the markings, or sculpturings, and those of "tektites" in general, as undoubtedly a consequence of their mode of origin, and as furnishing conclusive evidence of their ultra-terrestrial source. To this conclusion the present writer, as will be observed, takes decided exception, and has sought rather to explain them by comparing them with markings on pebbles of various kinds, concerning the origin of which there is no question.

(1) Obsidian pebbles from near Cali, Department of Cauca, Colombia, South America.-These were received at the Museum from a Mr. B. S. Hobbs through Dr. George F. Kunz, with the simple labeling "Obsidian" ${ }^{1}$ from the locality above given. Nothing is known regarding their occurrence, nor have I been able to get in communication with Mr. Hobbs with a view of acquiring further data.

As shown in the illustrations (pl. 62, figs. 1-2) of two of the larger forms, the specimens are roughly spherical, each showing on one side a flattened area as though it had at some time been attached to a larger mass or had remained in one position during the etching process, since the larger grooves are entirely absent from these portions. The surface markings are of three kinds: First, those which appear like original conchoidal fractures, the sharp angles of which have been reduced by corrosion; second, a series of shallow pits and grooves which are distributed fairly uniformly over the entire surface except the fattened portion mentioned; and, third, a very fine stipple-like pitting which gives the surface a shagreen-like appearence. This shagreen effect with numerous small, nearly circular, shallow pits occurs also on the flat areas where the larger groovings are lacking as already stated. The colors are dull black, but by transmitted light smoky brown. These two larger forms are roughly 20 and $30 \mathrm{~mm}$. in diameter, and weigh 12 and 30 grams, respectively. Thin sections under the microscope show a faint smoky glass almost completely isotropic, but with an occasional minute, colorless, doubly refracting point too small for satisfactory determination. A peculiar series of anastomizing cracks much resembling the crackle structure on certain porcelain glazes, traverses the section in all directions.

The composition of this glass, as shown by an analysis of a portion cut from the larger of the specimens, is given in column I below. In

\footnotetext{
1 Since the above was written, but before this paper was sent to press, I received from Dr. J. Woldrich, of Prag, a copy of his Beitrag zur Lösung der Tektitfrage, in which this and the Arizona samples are referred to. It will be observed that I still hold the opinion expressed in my letter to Doctor Woldrich and by him quoted.
} 
columns II to IV are given analyses of examples of tektites from Tasmania, Australia, and Bohemia for purposes of comparison. It may be well to note, incidentally, that H. S. Summers has discussed the various published analyses of the Australian "obsidianites" from the standpoint of the modern classification, and relegates them to the classes almerose, riesenose, urallaose, and piemenose.

Analyses of Tektites.

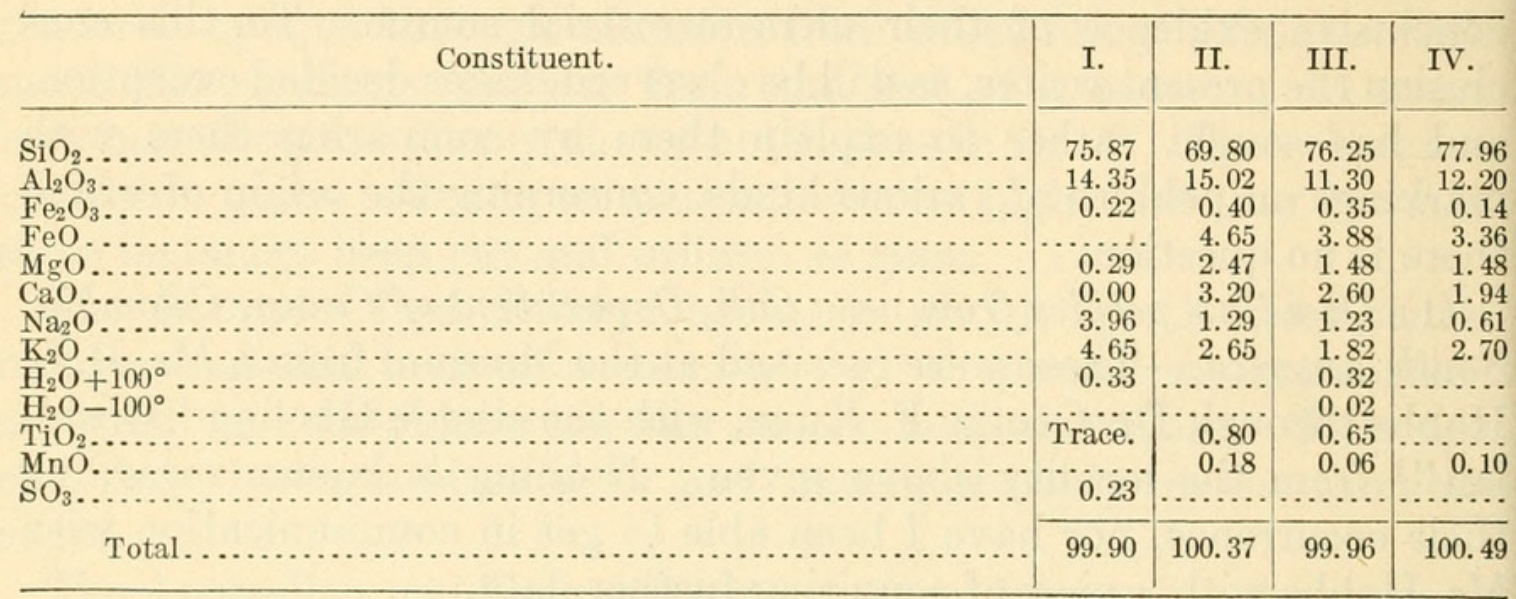

I. Obsidian pebble. Colombia. Analyst, J. E. Whitfield.

II. Obsidianite. Upper Weld, Tasmania. Analyst, W. F. Hillebrand.

III. Obsidianite. Near Hamilton, Victoria. Analyst, G. Ampl.

IV. Moldavite. Tribitsch, Bohemia.

Although data are lacking regarding the mode of occurrence of this Colombian material, it is at once evident that we are dealing with a not unusual type of terrestrial obsidian.

(2) Obsidian pebbles, Clifton, Arizona (Cat. No. 53676).-These pebbles were received at the Museum in 1889 from Mr. Frank Keppler. There is apparently no question but what they are water-worn and corroded pebbles of ordinary obsidian. They are dark, smoky black in color, and show under the microscope the characteristic black hairlike trichites. The surfaces are roughened by pits and grooves, as shown somewhat enlarged in pl. 62, fig. 3. In addition the entire surface is shagreened.

(3) Obsidian pebbles, near Marsh, Idaho (Cat. No. 77784).-These pebbles, again, are of ordinary black obsidian, and were collected by Dr. W. Lindgren, of the U. S. Geological Survey, in gravel beds some $4 \frac{3}{4}$ miles north and 20 degrees west of Marsh. The surfaces, as shown in pl. 62, fig. 4, are everywhere pitted and grooved, but the elongated, curvilinear, and lunar crater forms so characteristic of the billitonites are quite lacking. The surfaces are coated with a thin, mammilated crust, which is in part a secondary deposit of iron.

(4) Obsidian pebble, High Rock Canyon, Nevada (Cat. No. 35270).This pebble (pl.62, fig. 5) is of a coal black obsidian, only faintly translucent on the thin edges. The surface, it will be noted, is etched in a manner strikingly suggestive of the billitonites, even to the nearly 
circular lunar crater forms, as they may be termed. The surface is also considerably abraded as though the pebble had been rolled about on a beach, and the bottoms of the grooves, or flutings, are coated with a dull brown-red material, which seems to be an original constituent rather than an extraneous substance deposited from the water as was at first supposed. It is probably a devitrification product similar to that found in the lithophysæ of obsidians. The specimen, which is about $12 \mathrm{~cm}$. by $9 \mathrm{~cm}$. by $4 \mathrm{~cm}$. in thickness, was brought in many years ago by Prof. I. C. Russell and is labeled simply "Obsidian pebble," and from the locality above given.

These same markings I find roughly simulated on some large weathered obsidian pebbles sent me by Dr. J. Aguilera from between Guajolote hill and Cuyamaloya, Hidalgo, Mexico.

(5) Obsidian, near Myvatu, Iceland (Cat. No. 77616).-Perhaps the most strikingly billiton-like markings found on any of the terrestrial rocks which have come under the author's observation are those on some obsidians brought by Dr. F. E. Wright from a flow at Hrafntinnuhyggur, near Myvatu as above noted. The specimens were collected by Doctor Wright in 1909, and briefly described by him at the December, 1910, meeting of the Geological Society of America, an abstract of three lines only appearing in the bulletin for that year. The material is a highly lustrous jet black glass, the outer surfaces of which are grooved and etched to a maximum depth of 2 or $3 \mathrm{~mm}$., as shown in pl. 62, fig. 6 . Not only are the lunar crater forms here in evidence, but there are also. elongated, nearly straight grooves which, but for the position they occupy on the surface, might at first be thought to have been produced by the scoring of one mass against another while in a plastic condition. On one surface of this specimen, which unquestionably represents a more recent fracture than that of the surface shown in the figure, are found only the minute circular pittings such as were described as occurring on the flattened areas of the specimens from Colombia.

To still further test the possibilities of a terrestrial origin, fragments of dark obsidian from near Reno, Nevada, and Yucca, in Mohave County, Arizona, were submitted for a few days to the action of dilute fluorhydric acid. The resultant forms are shown in figs. 7-9 on pl. 62 , fig. 9 , it will be noted, compares very closely with the slaglike pieces in fig. 6 of pl. 61 .

In referring to the above described materials attention needs first to be called to the fact that the markings on these pebbles and obsidians of known terrestrial origin more closely agree with those on the tektites than do the tektitesfrom various localities agree among themselves; and, further, that the etchings produced by action of fluorhydric acid are practically indistinguishable from the markings on some of the moldavites. Further than this, the markings on the 
tektites from various sources are so wholly unlike that it is impossible to conceive of their having a common origin, or been formed through the same agencies, and above all it is to be noted that in no case do they resemble the flutings which are characteristic of known meteorites. This, it seems to me, can not be accounted for on the ground of their superior refractibility, but as rather indicating an entirely different origin. Further than this again, the smaller meteoric stones, those corresponding in size with the tektites, rarely if ever show pittings and flutings. It is only the larger forms apparently which hold their orientation for a sufficient length of time for flutings to develop. The smaller forms are mere rounded blebs as is abundantly illustrated by the hundreds of individuals constituting the Pultusk and other noted falls. I can not, therefore, at all agree with Suess in his conclusions on this branch of the subject. Whatever may have been their original source, the Bohemian and Moravian specimens are now simply water-worn pebbles of weathered glass, originally etched by corroding vapors or solutions, the results being indistinguishable from those produced by artificial etchings on obsidian with fluorhydric acid. The Australian forms are likewise, to me, simply pebbles of glass which have been water worn or abraded by wind-blown sands. In their contours there is nothing even suggestive of meteoric markings, nor do I find any semblance of such an origin so far as the surface markings alone are concerned in the examples from Billiton. I do not, however, agree with Dr. G. F. Kunz ${ }^{1}$ in regarding the pittings as due to "large bubble cavities that have been broken into by attrition."

In the above, it will be noted, I do not attempt or wish to controvert the theory of a cosmic origin for these very remarkable and interesting bodies. Until, however, such shall be seen to fall, it would seem that the explanation of their source or origin is to be found only in the conditions under which they occur and their somewhat anomalous composition.

\section{EXPLANATION OF PLATES.}

Plate 61.

Figs. 1 to 3.-Billitonites from the island of Billiton.

4 to 6. Moldavites from Moldavia and Bohemia.

7 to 9 . Australites and an Obsidian button from Australia.

\section{Plate 62.}

Figs. 1 and 2. Moldavite-like Obsidian pebbles from Cali, in Colombia, South America.

Fig. 3. Obsidian pebble from Clifton, Arizona.

4. Obsidian pebble from near Marsh, Idaho.

5. Obsidian pebble from High Rock Canyon, Nevada.

6. Obsidian from Obsidian flow near Myvatu, Iceland.

7-9. Obsidian pebbles etched by fluorhydric acid. 


\section{$2 \mathrm{BHL}$ Biodiversity Heritage Library}

Merrill, George P. 1911. "On the supposed origin of the moldavites and like sporadic glasses from various sources." Proceedings of the United States National Museum 40(1833), 481-486.

https://doi.org/10.5479/si.00963801.40-1833.481.

View This Item Online: https://www.biodiversitylibrary.org/item/53820

DOI: https://doi.org/10.5479/si.00963801.40-1833.481

Permalink: https://www.biodiversitylibrary.org/partpdf/53290

\section{Holding Institution}

Smithsonian Libraries

\section{Sponsored by}

Smithsonian

\section{Copyright \& Reuse}

Copyright Status: Public domain. The BHL considers that this work is no longer under copyright protection.

This document was created from content at the Biodiversity Heritage Library, the world's largest open access digital library for biodiversity literature and archives. Visit BHL at https://www.biodiversitylibrary.org. 